\section{Qualitative and Quantitative Differences in the Pathways of Extrathyroidal Triiodothyronine Generation between Euthyroid and Hypothyroid Rats}

\author{
J. Enrique Silva, Murray B. Gordon, Frank R. Crantz, \\ Jack L. Leonard, and P. Reed Larsen \\ Howard Hughes Medical Institute Laboratory, Department of \\ Medicine, Brigham and Women's Hospital, \\ Harvard Medical School, Boston, Massachusetts 02115
}

A inhibitory doses for liver and kidney iodothyronine 5 'deiodinase activity $\left(5^{\prime} \mathrm{D}-\mathrm{I}\right)$, reduces extrathyroidal $\mathrm{T} 4$ to T3 conversion by only $60-70 \%$ in euthyroid rats. A second pathway of T4 to T3 conversion ( $5^{\prime} \mathrm{D}$-II) has been found in pituitary, central nervous system, and brown adipose tissue. 5'D-II is insensitive to PTU and increases in hypothyroidism, whereas 5'D-I decreases in hypothyroid rats. Thyroxine (T4) and triiodothyronine (T3) kinetics were assessed in euthyroid and thyroidectomized rats by noncompartmental analysis after injecting $\left[{ }^{125} \mathrm{I}\right] \mathrm{T} 4$ and ${ }^{[131}$ I]T3. Neither the volume of distribution nor the rate of fractional removal of plasma $\mathrm{T} 4$ was affected by the thyroid status, but the fractional removal rate of T3 was $\sim 50 \%$ reduced in hypothyroid rats $(P<0.001)$. Fractional T4 to T3 conversion was $22 \%$ in euthyroid and $26 \%$ in hypothyroid rats. In euthyroid rats, sufficient PTU to inhibit liver and kidney $5^{\prime} \mathrm{D}-\mathrm{I}>90 \%$ reduced serum $\left[{ }^{125} \mathrm{I}\right] \mathrm{T} 3$ after $\left[{ }^{125} \mathrm{I}\right] \mathrm{T} 4$ (results given as percent dose per milliliter $\times 10^{-3} \pm$ SEM): $4 \mathrm{~h}$, control $16 \pm 2$ vs. PTU $4 \pm 1$, $P<0.005$, and $22 \mathrm{~h}$, control $6.4 \pm 0.4$ vs. PTU $3.6 \pm 0.7$, $P<0.025$. In thyroidectomized rats, the same dose of PTU also inhibited 5'D-I in liver and kidney, but had no effect on the generation of serum $\left[{ }^{125} \mathrm{I}\right] \mathrm{T} 3$ from $\left[{ }^{125} \mathrm{I}\right] \mathrm{T} 4$. Similarly, after $1 \mu \mathrm{g} \mathrm{T} 4 / 100 \mathrm{~g}$ bw was given to thyroidectomized rats, serum T3 (radioimmunoassay) increased

Dr. Leonard is the recipient of a New Investigator Award (AM-30309). Address all correspondence to Dr. Silva, Thyroid Diagnostic Center, Brigham and Women's Hospital, 75 Francis St., Boston, MA 02115.

Received for publication 18 July 1983 and in revised form 28 November 1983.

J. Clin. Invest.

(C) The American Society for Clinical Investigation, Inc.

0021-9738/84/04/0898/10 \$1.00

Volume 73, April 1984, 898-907 by $0.30 \pm 0.6 \mathrm{ng} / \mathrm{ml}$ in controls and $0.31 \pm 0.09 \mathrm{ng} / \mathrm{ml}$ in PTU-treated rats. However, when the dose of T4 was increased to $2-10 \mu \mathrm{g} / 100 \mathrm{~g}$ bw, PTU pretreatment significantly reduced the increment in serum T3. T3 clearance was not affected by PTU in hypothyroid rats. The 5'D-II in brain, pituitary, and brown adipose tissue was reduced to $\leq 60 \%$ of control by $30 \mu \mathrm{g} / 100 \mathrm{~g}$ bw reverse T3 (rT3), an effect that lasted for at least $3 \mathrm{~h}$ after rT3 had been cleared. In rT3-pretreated thyroidectomized rats, the generation of $\left[{ }^{125} \mathrm{I}\right] \mathrm{T} 3$ from tracer $\left[{ }^{125} \mathrm{I}\right] \mathrm{T} 4$ was reduced in the serum: $6 \pm 1$ vs. $12 \pm 1 \times 10^{-3} \%$ dose $/ \mathrm{ml}, P<0.01$, during this $3-\mathrm{h}$ period.

We conclude that virtually all the $\mathrm{T} 3$ produced from low doses of exogenous T4 given to hypothyroid rats is generated via a PTU-insensitive pathway, presumably catalyzed by the $5^{\prime} \mathrm{D}$-II. This is a consequence of the enhanced activity of this low $K_{\mathrm{m}}$ enzyme together with the concomitant decrease in the hepatic and renal 5'D-I characteristic of the hypothyroid state. The results indicate that in some circumstances, 5'D-II activity may contribute to the extracellular, as well as intracellular, T3 pool.

\section{Introduction}

In euthyroid man and rat, most of the serum triiodothyronine (T3) ${ }^{1}$ is generated from $5^{\prime}$-deiodination of thyroxine (T4) (1$3)$. Given the comparatively high concentration of a membranebound iodothyronine-5'-deiodinase in liver and kidney, these tissues are considered to be the main source of extrathyroidally produced T3 (4-6). One of the characteristics of this enzyme is to be uncompetitively inhibited by propylthiouracil (PTU)

1. Abbreviations used in this paper: bw, body weight; BAT, brown adipose tissue; 5'D-I, liver and kidney 5'-deiodinase enzyme; PTU, propylthiouracil; rT3, reverse T3; Tx, thyroidectomized rats; T4, thyroxine; T3, triiodothyronine; 5'D-II, type II 5'-deiodinase enzyme. 
(7); the drug inhibits the enzyme whether it is added in vitro or given in vivo (8). PTU injected into thyroidectomized-T4replaced rats reduces serum T3 by $60-70 \%$ (9), although in similarly treated animals, T4 to T3 conversion in liver and kidney is reduced $\sim 90 \%(10,11)$.

Recently, we have observed that $\left[{ }^{125} \mathrm{I}\right] \mathrm{T} 4$ to $\left[{ }^{125} \mathrm{I}\right] \mathrm{T} 3$ conversion in vivo is different in various tissues (12). In cerebral cortex, cerebellum, and pituitary all $\left[{ }^{125} \mathrm{I}\right] \mathrm{T} 3$ formed in situ is insensitive to the inhibition by PTU, whereas in the liver and serum of the same animals, pretreatment with PTU reduces the accumulation of $\left[{ }^{125} \mathrm{I}\right] \mathrm{T} 3$ by $60 \%$. In vitro studies have shown that the former tissues indeed have a unique iodothyronine $5^{\prime}$ deiodinase, which is different from the one present in liver and kidney in many respects, among others, being insensitive to PTU and having a low apparent $K_{\mathrm{m}}(1-2 \mathrm{nM})$ for the substrates T4 and reverse T3 $(r T 3)(13,14)$. We have termed this enzyme type II $5^{\prime}$-deiodinase (5'D-II) to differentiate from the liver and kidney 5 -deiodinase enzyme, 5 'D-I. Brown, but not white, adipose tissue has recently been found to contain significant quantities of 5'D-II (15) but our efforts to demonstrate measurable amounts of this enzyme in other tissues, including liver and kidney, have been unsuccessful. Another important characteristic of $5^{\prime} \mathrm{D}$-II is that the tissue levels increase as serum $\mathrm{T} 4$ decreases (16). Thus, $5^{\prime} \mathrm{D}$-II is 4-5-fold more abundant in the cerebral cortex, pituitary, and brown adipose tissue (BAT) from hypothyroid than in euthyroid adult rats. In contrast, 5'D-I activity is reduced by $50 \%$ in hypothyroid and euthyroid liver and kidney.

The incomplete inhibition of serum and liver T3 accumulation in vivo suggests that as much as $30-40 \%$ of the serum T3 generated from T4 may occur via 5'D-II in euthyroid rats $(8,9,12)$. Given the changes in $5^{\prime} \mathrm{D}-\mathrm{I}$ and $5^{\prime} \mathrm{D}-\mathrm{II}$ observed in hypothyroidism, a larger fraction of $\mathrm{T} 4$ could be converted to T3 via this pathway. When T4 is provided to thyroidectomized rats $(\mathrm{T} x)$ the fraction converted to $\mathrm{T} 3$ could be normal, or even increased, in spite of a reduction of 5'D-I activities in kidney and liver. The ensuing studies were undertaken to answer the question of whether or not $5^{\prime} \mathrm{D}-\mathrm{II}$ is an important pathway of peripheral $\mathrm{T} 3$ production in hypothyroidism.

\section{Methods}

Male adult Sprague-Dawley rats (Zivic Miller, Allison Park, PA or Charles River Breeding Labs Inc., Wilmington, MA) were used throughout. Thyroidectomy followed by parathyroid reimplant was performed by the supplier (Zivic Miller). Rats were used at least $6 \mathrm{wk}$ after thyroidectomy, the completeness of which was confirmed by reduced serum $\mathrm{T} 4$ and $\mathrm{T} 3$ concentrations.

[ $\left.{ }^{125} \mathrm{I}\right] \mathrm{T} 4$ (sp act $\sim 4,200 \mu \mathrm{Ci} / \mu \mathrm{g}$ ), [ $\left.{ }^{131} \mathrm{I}\right] \mathrm{T} 3$ (sp act $\sim 2,800 \mu \mathrm{Ci} / \mu \mathrm{g}$ ), and [ $\left.{ }^{125} \mathrm{I}\right] \mathrm{rT} 3$ (sp act $\sim 2,800 \mu \mathrm{Ci} / \mu \mathrm{g}$ ) were prepared in the laboratory after procedures previously published with only minor modifications $(17,18)$. Tracers were stored at $0-4^{\circ} \mathrm{C}$ in $70 \%$ ethanol and used within 1 wk of synthesis. At the time of injection, the appropriate volume was dried under $\mathrm{N}_{2}$ and resuspended in $0.9 \% \mathrm{NaCl} /$ normal rat serum (9:1) containing $10 \mathrm{mg} / \mathrm{ml} \mathrm{NaI}$. Tracers were injected intravenously, usually mixed, in boluses of 0.1 or $0.2 \mathrm{ml} / \mathrm{rat}$.

Unlabeled T4 and $\mathrm{rT} 3$ were injected intraperitoneally or intravenously in the same vehicle as the tracers, at concentrations calculated to deliver the desired amount in $0.1 \mathrm{ml} / 100 \mathrm{~g}$ body weight (bw). Doses, time, and site of injection are indicated with the description of each experiment.

PTU was dissolved in $1.5 \mathrm{~N} \mathrm{NaOH}$, in one-tenth of the final volume, and then diluted with water to the desired concentration to inject a 0.1 $0.2 \mathrm{ml} / 100 \mathrm{~g} \mathrm{bw}$; when necessary, $\mathrm{pH}$ was reduced to $10-11$ with $\mathrm{H}_{3} \mathrm{PO}_{4}$. All injections were given intraperitoneally in doses and at times indicated for individual experiments.

In vivo studies of T4 and T3 distribution and disposal. Fractional T4 to T3 conversion. Euthyroid or hypothyroid rats were injected with $60-100 \mu \mathrm{Ci}$ of $\left[{ }^{125} \mathrm{I}\right] \mathrm{T} 4$ and $20 \mu \mathrm{Ci}$ of $\left[{ }^{131} \mathrm{I}\right] \mathrm{T} 3$ and serum levels of $\left[{ }^{125} \mathrm{I}\right] \mathrm{T} 4,\left[{ }^{131} \mathrm{I}\right] \mathrm{T} 3$, and $\left[{ }^{125} \mathrm{I}\right] \mathrm{T} 3$ from $\mathrm{T} 4$ ([ $\left.\left.{ }^{125} \mathrm{I}\right] \mathrm{T} 3[\mathrm{~T} 4]\right)$ were measured for $24 \mathrm{~h}$. Five-tenths to $0.6 \mathrm{ml}$ of blood was obtained from the heart under light ether anesthesia. Two experiments, I and II, were performed in euthyroid rats and one using hypothyroid rats. In experiment $I$, three groups of three, and in experiment II and that with hypothyroid rats, four groups of four rats were bled alternatively between 30 and $24 \mathrm{~h}$ after the tracers were injected. Thus, each group of rats was bled no more than three times with an interval of at least $3 \mathrm{~h}$ to avoid the stress of repeated bleeding. The detailed schedules of bleeding are presented under Table I.

Serum [ $\left.{ }^{125} \mathrm{I}\right] \mathrm{T} 4$ and $\left[{ }^{131} \mathrm{I}\right] \mathrm{T} 3$ were separated by paper chromatography. When there were $>1,000 \mathrm{cpm}$ of the least abundant isotope in $20 \mu \mathrm{l}$ of serum, this volume was directly applied to chromatography paper (Whatman filter paper no. $3 \mathrm{MM}$ ) and followed, while still wet, by 50 $\mu l$ of ethanol/2 $\mathrm{N} \mathrm{NH}_{4} \mathrm{OH}$ (9:1) containing $2 \mathrm{mg} / \mathrm{ml} \mathrm{T4}, \mathrm{T} 3$, and $\mathrm{NaI}$ (marker). The latter were used as markers for chemical stains. When fewer than the above number of counts were present, the appropriate volume of serum $(30-50 \mu \mathrm{l})$ was extracted with $50 \mu \mathrm{l}$ of marker and $100 \mu \mathrm{l}$ of butanol saturated with $2 \mathrm{~N} \mathrm{NH}_{4} \mathrm{OH}$; the precipitate was reextracted with $150 \mu$ l ethanol/butanol (1:2) saturated with $2 \mathrm{~N} \mathrm{NH}_{4} \mathrm{OH}$ the extracts pooled and applied to paper. This procedure allowed overall extraction of $>90 \%$ of the counts. Chromatograms were developed for 18-24 $\mathrm{h}$ in tertiary amyl alcohol/hexane/2 $\mathrm{N} \mathrm{NH}_{4} \mathrm{OH}(5: 1: 6)$. 20-50 $\mu \mathrm{l}$ of each serum were counted along with the T3 and T4 spots from the chromatograph and the radioactivity expressed as percent injected dose per milliliter. The concentrations of $\left[{ }^{125} \mathrm{I}\right] \mathrm{T} 4$ and $\left[{ }^{131} \mathrm{I}\right] \mathrm{T} 3$ were calculated from the total serum radioactivity and the fraction of counts recovered as $\left[{ }^{125} \mathrm{I}\right] \mathrm{T} 4$ and $\left[{ }^{131} \mathrm{I}\right] \mathrm{T} 3$ in the corresponding spots.

Serum [ $\left.{ }^{125} \mathrm{I}\right] \mathrm{T} 3$ was measured by a combination of affinity and paper chromatography (19). The serum $(0.1 \mathrm{ml})$ was first chromatographed through a $0.3-\mathrm{ml}$ bed-volume-column of Sepharose to which anti-T3 antibody had been conjugated. After elution of non-T3 counts with 0.1 M Na-phosphate buffer, pH 7.1, both [ $\left.{ }^{125} \mathrm{I}\right] \mathrm{T} 3$ and $\left[{ }^{131} \mathrm{I}\right] \mathrm{T} 3$ were eluted with methanol/2 $\mathrm{N} \mathrm{NH}_{4} \mathrm{OH}(9: 1)$. The eluates were dried under $\mathrm{N}_{2}$ and applied to paper. This step reduces markedly the [ $\left.{ }^{125} \mathrm{I}\right] \mathrm{T} 4$ to $\left[{ }^{125} \mathrm{I}\right] \mathrm{T} 3$ ratio. Typically, $50-60 \%$ of the ${ }^{125} \mathrm{I}$-counts in the eluate are $\left[{ }^{125} \mathrm{I}\right] \mathrm{T} 3$, $30-40 \%$ [ $\left.{ }^{125} \mathrm{I}\right] \mathrm{T} 4$, and the rest are distributed evenly along the rest of the paper strip; $85 \%$ of the ${ }^{131} \mathrm{I}$-counts are $\left[{ }^{131} \mathrm{I}\right] \mathrm{T} 3$. The latter was used as an internal recovery standard since the total concentration in the serum was known from direct chromatography. Recovery of T3 in the eluates was 50-60\%. The concentration of $\left[{ }^{125} \mathrm{I}\right] \mathrm{T} 3$ was then expressed as percentage of the $\left.{ }^{125} \mathrm{I}\right] \mathrm{T} 4$ injected. This figure was corrected for the small amount of $\left[{ }^{125} \mathrm{I}\right] \mathrm{T} 3$ contaminating the injected [ $\left.{ }^{125} \mathrm{I}\right] \mathrm{T} 4$ as follows: since the distribution and clearance of this radiolabeled T3 is the same as that of simultaneously injected $\left.{ }^{131} \mathrm{I}\right] \mathrm{T} 3$, and the concentration of the latter was known for each sample, the serum concentration of $\left[{ }^{125} \mathrm{I}\right] \mathrm{T} 3$ injected, i.e., contaminating the $\left[{ }^{125} \mathrm{I}\right] \mathrm{T} 4$, could be calculated: (percent $\left[{ }^{125} \mathrm{I}\right] \mathrm{T} 3$ in $\left[{ }^{125} \mathrm{I}\right] \mathrm{T} 4$ dose $\left.\div 100\right) \times\left(\right.$ serum $\left.\left[{ }^{131} \mathrm{I}\right] \mathrm{T} 3\right)$, expressed as percentage of the $\left[{ }^{131} \mathrm{I}\right] \mathrm{T} 3$ dose. This number was subtracted from the observed 
[ $\left.{ }^{125} \mathrm{I}\right] \mathrm{T} 3$. The residual $\left[{ }^{125} \mathrm{I}\right] \mathrm{T} 3$ counts were multiplied by two because of the loss of one atom of ${ }^{125} \mathrm{I}$ in the process of conversion. Contaminating [125I]T3 was $<10 \%$ of the total $\left[{ }^{125} \mathrm{I}\right] \mathrm{T} 3$ at all times after $2 \mathrm{~h}$ post injection. In the above extraction procedure, the serum samples were thawed and immediately put in the T3-antibody Sepharose column. Over 95\% of the $\left.{ }^{125} I\right] T 4$ did not bind to the column, i.e., came out in the first eluate, whereas $>60 \%$ of the $\left[{ }^{125} \mathrm{I}\right] \mathrm{T} 3$ and $\left[{ }^{131} \mathrm{I}\right] \mathrm{T} 3$ remained bound to the fixed antibody. To determine whether there was artifactual T4 to T3 conversion during this procedure, the first eluate from one column, containing $\sim 95 \%$ of the $\left[{ }^{125} \mathrm{I}\right] \mathrm{T} 4$ and $<60 \%$ of the $\left[{ }^{125} \mathrm{I}\right] \mathrm{T} 3$ was rechromatographed successively through three columns. Each of the columns was handled as described above for the serum samples. One-fourth of $1 \%$ of the ${ }^{125}$ I-counts were T3 after the first column, as per the second column; this figure decreased to $0.10 \%$, and became negligible in the subsequent columns, which indicated there was no artifactual conversion. Had conversion taken place, a constant percent of $\left[{ }^{125} \mathrm{I}\right] \mathrm{T} 4$ put into each column would have been recovered as [ $\left.{ }^{125} \mathrm{I}\right] \mathrm{T} 3$.

The serum concentrations of all three radiolabeled iodothyronines were normalized to $200 \mathrm{~g}$ to avoid this source of variation. In all four experiments performed to determine kinetic parameters the early serum concentrations correlated inversely with the body weight (coefficients of correlation ranging from -0.84 to -0.97 ). The weights of the animals are given in Table $\mathbf{I}$.

The data on $\left[{ }^{131} \mathrm{I}\right] \mathrm{T} 3$ and $\left[{ }^{125} \mathrm{I}\right] \mathrm{T} 4$ were analyzed by noncompartmental analysis $(20,21)$; the fractional conversion was also calculated based on the same principles. It was assumed that the clearance of $\mathrm{T} 3$ entering the bloodstream was the same regardless of the site and rate of entrance. Support for this assumption has been obtained from the comparison of the serum concentrations of $\left.{ }^{125} \mathrm{I}\right] \mathrm{T} 3$ injected intravenously with those obtained from simultaneous subcutaneous injection of $\left.{ }^{131} \mathrm{I}\right] \mathrm{T} 3$ in 0.1 $\mathrm{ml}$ of human serum (Silva, J. E., submitted for publication). The areas under the curves described by both radiolabeled T3's were identical and, since the absorption of the subcutaneously injected T3 was complete, the clearances were also identical. Thus, the areas under the curves from time 0 to infinity of [ $\left.{ }^{125} \mathrm{I}\right] \mathrm{T} 3(\mathrm{~T} 4), \mathrm{T} 3$ derived from $\left[{ }^{125} \mathrm{I}\right] \mathrm{T} 4$, and $\left[{ }^{131} \mathrm{I}\right] \mathrm{T} 3$ should be proportional to the respective "doses"; i.e., the area under the curve of [ $\left.{ }^{125} \mathrm{I}\right] \mathrm{T} 3$ (T4) should be proportional to the fraction of the total [ [25I]T4 converted to T3: dose [ $\left.{ }^{125} \mathrm{I}\right] \mathrm{T} 3(\mathrm{~T} 4)=\left(\int_{0}^{\infty}\left[{ }^{125} \mathrm{I}\right] \mathrm{T} 3[\mathrm{~T} 4] \mathrm{d} t\right.$ $\left.\div \int_{0}^{\infty}\left[{ }^{[31} \mathrm{I}\right][\mathrm{T} 3] \mathrm{d} t\right) \times 100=$ percent of $\left[{ }^{125} \mathrm{I}\right] \mathrm{T} 4$ converted to $\left[{ }^{125} \mathrm{I}\right] \mathrm{T} 3$.

The integrated serum concentrations of both radiolabeled T3's were obtained by direct planimetry from 0 to $24 \mathrm{~h}$ after the injections and thereafter were calculated assuming that the levels decreased approaching a single exponential $(20,21)$. In the case of $\left[{ }^{125} \mathrm{I}\right] \mathrm{T} 3(\mathrm{~T} 4)$ the terminal slope approaches that of the precursor, [ ${ }^{125}$ I]T4:

$$
\int_{24}^{\infty}\left[{ }^{125} \mathrm{I}-\mathrm{T} 3(\mathrm{~T} 4)\right] \mathrm{d} t=\int_{24}^{\infty}\left[{ }^{125} \mathrm{I}-\mathrm{T} 3(\mathrm{~T} 4)\right] \times \mathrm{e}^{-\lambda t} \mathrm{~d} t=\frac{\left[{ }^{125} \mathrm{I}-\mathrm{T} 3(\mathrm{~T} 4)\right]_{24}}{\lambda_{4}}
$$

where $\left[{ }^{125} \mathrm{I}-\mathrm{T} 3(\mathrm{~T} 4)\right]_{24}$ is the serum concentration of $\left[{ }^{125} \mathrm{I}\right] \mathrm{T} 3(\mathrm{~T} 4)$ at $24 \mathrm{~h}$, and $\lambda_{4}$ is the fractional removal rate of T4.

The error of this approximation ultimately depends on the time at which the rate of decrease of serum [ $\left.{ }^{125} \mathrm{I}\right] \mathrm{T} 3$ (T4) becomes indistinguishable from $\lambda_{4}$. In turn, this time depends on the differences between $\lambda_{3}$ and $\lambda_{4}$, the fractional rates of disappearance of T3 and T4, respectively, and on how much [ $\left.{ }^{125} \mathrm{I}\right] \mathrm{T} 4 \mathrm{remains}$ at $24 \mathrm{~h}$. Because of the rapid disappearance of $\left[{ }^{131} I\right] T 3$ and $\left[{ }^{125} I\right] T 4$, and the difference between $\lambda_{3}$ and $\lambda_{4}$ in euthyroid animals, the error is minimal. However, in hypothyroid rats (see Table I and Fig. 2) the rate of disappearance of [ [25I]T3(T4) is still $<\lambda_{4}$ at 24 $h$ and, therefore, a significant error may result. As shown in Appendix
II, correcting the error in this approximation requires multiplying the $\int_{24}^{\infty}\left[{ }^{125} \mathrm{I}-\mathrm{T} 3(\mathrm{~T} 4)\right] \mathrm{d} t$ by 1.26 .

Effect of PTU on T4 to T3 conversion. PTU was injected in various dosages to find the lowest dose that would decrease liver and kidney 5'deiodinase by $>90 \%$ and in subsequent experiments was given in doses equal or greater than that dose. The effect of the drug was assessed in vivo by tracer $\mathrm{T} 4$ to $\mathrm{T} 3$ conversion as well as by $\mathrm{T} 3$ accumulation after different doses of unlabeled T4. To assess further the source of serum T3 after T4, 5'D-II was also manipulated by pretreating hypothyroid rats with reverse $\mathrm{T} 3$ in doses that are maximally inhibitory for 5'D-II (22).

Radioimmunoassay (RIA). Serum T4 and T3 were measured by previously described radioimmunoassays (23) using rat thyroid hormonefree serum in the standard curve for T3 and human thyroid hormonefree serum for $\mathrm{T} 4$.

Enzyme assays. Iodothyronine 5'-deiodinase type I and II were measured as previously described (12). Type II 5 D is defined as T4 to T3 converting activity or rT3 5'-deiodination in the presence of $1 \mathrm{mM} \mathrm{PTU}$; the two methods give identical results $(12,16)$. Enzyme activity was assayed in crude homogenates or the infranatants of brown adipose tissue homogenates (15).

Statistical analysis was performed by paired and unpaired $t$ tests and analyses of variance when indicated.

\section{Results}

T4 and T3 kinetics in euthyroid and hypothyroid rats. Disappearance curves of $\left[{ }^{125} \mathrm{I}\right] \mathrm{T} 4$ and $\left[{ }^{131} \mathrm{I}\right] \mathrm{T} 3$ are shown in Fig. 1. The results of the two experiments done in euthyroid rats are depicted by different closed symbols.

The kinetic parameters derived from the data in Fig. 1 are shown in Table I. Since the parameters obtained by noncompartmental analyses are the composite figure obtained from the integrated plasma concentrations of several groups of rats in each experiment, there was no way to assess the statistical level of significance of the differences. However, the close agreement between the figures obtained by single compartmental analyses with those obtained by noncompartmental analyses allowed us to get an estimate of the significance of some of the differences. Although both the volume of distribution of T4 and the fractional removal rate of $\mathrm{T} 3$ were significantly reduced in hypothyroidism, the reduction in T4 volume of distribution was dependent upon the modeling because the value obtained by noncompartmental analyses in hypothyroid rats was not different from that observed in euthyroid rats. The reduction of the rate of irreversible removal of T3 in hypothyroid rats seemed clear and independent of the modeling. Notwithstanding all the restrictions in the statistical analyses, the calculated clearance of $\mathrm{T} 3$ and $\mathrm{T} 4$ by noncompartmental analyses were $40-50 \%$ reduced in hypothyroidism.

The curves describing the appearance of the serum $\left[{ }^{125} \mathrm{I}\right] \mathrm{T} 3(\mathrm{~T} 4)$ are shown in Fig. 2 . In euthyroid rats we observed an early peak followed by a broader wave of accumulation, whereas in hypothyroid rats such an early peak was not seen. However, the calculated fractional T4 to T3 conversion was $\sim 22 \%$ in euthyroid and $\sim 26 \%$ in hypothyroid rats. As shown in Table I, since the fractional removal rate of $\left[{ }^{125} \mathrm{I}\right] \mathrm{T} 4$ was 


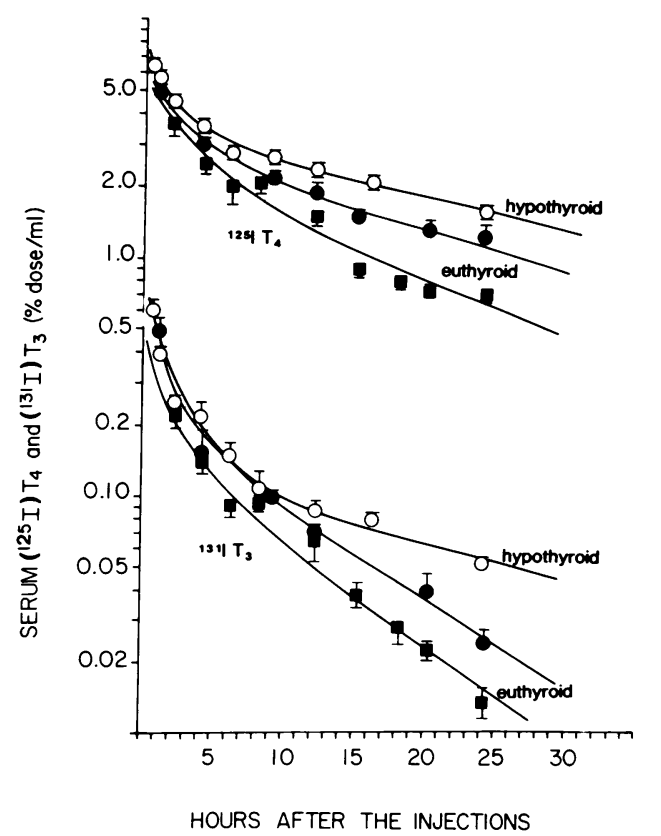

Figure 1. Time course of disappearance of $\left[{ }^{125} \mathrm{I}\right] \mathrm{T} 4$ and $\left[{ }^{131} \mathrm{I}\right] \mathrm{T} 3$ from the serum after the intravenous injection of both tracers. Concentrations are expressed as percent dose per milliliter normalized to $200 \mathrm{~g}$ bw. The open circles are data from hypothyroid rats and the closed symbols result from two different experiments performed in euthyroid rats. In these experiments, groups of three rats (experiment I euthyroid rats, filled circles), or four rats each (experiment II euthyroid rats, filled squares, and hypothyroid rats, open circles), were bled two or three times with the schedule described in Table I.

reduced in hypothyroid rats, the fraction of $\mathrm{T} 4$ converted to $\mathrm{T} 3$ per day was $\sim 15 \%$ in both euthyroid and hypothyroid rats.

Effects of PTU on extrathyroidal T3 production in euthyroid and hypothyroid rats. We used PTU to explore the enzymatic pathway of extrathyroidally generated serum T3 in euthyroid and hypothyroid animals. In the experiment shown in Table II, euthyroid and hypothyroid rats were given $2 \mathrm{mg}$ of PTU/ $100 \mathrm{~g}$ bw $4 \mathrm{~h}$ before and at the time of $\left[{ }^{125} \mathrm{I}\right] \mathrm{T} 4$ and $\left[{ }^{131} \mathrm{I}\right] \mathrm{T} 3$ injections. Serum $\left[{ }^{125} \mathrm{I}\right] \mathrm{T} 4,\left[{ }^{125} \mathrm{I}\right] \mathrm{T} 3(\mathrm{~T} 4)$, and $\left[{ }^{131} \mathrm{I}\right] \mathrm{T} 3$ were measured 4 and $22 \mathrm{~h}$ after injection. At both times, serum [ $\left.{ }^{125} \mathrm{I}\right] \mathrm{T} 4$ and $\left[{ }^{131} \mathrm{I}\right] \mathrm{T} 3$ concentrations were higher in hypothyroid rats $(P$ $<0.001$ ), but PTU did not affect the concentrations of these iodothyronines in either state. While at $4 \mathrm{~h}$ the serum concentration of $\left[{ }^{125} \mathrm{I}\right] \mathrm{T} 3$ (T4) was not affected by hypothyroidism, at $22 \mathrm{~h}$ it was higher in hypothyroid animals, which was consistent with the data in Fig. 2. Pretreatment with PTU reduced the serum concentration of $\left[{ }^{125} \mathrm{I}\right] \mathrm{T} 3(\mathrm{~T} 4)$ in euthyroid rats by $75 \%$ at $4 \mathrm{~h}(P<0.005)$, and by $44 \%$ at $22 \mathrm{~h}(P<0.025)$. In contrast, this drug did not reduce the serum [ $\left.{ }^{125} \mathrm{I}\right] \mathrm{T} 3(\mathrm{~T} 4)$ concentration in hypothyroid rats. Because of the decreased clearance of T3 in hypothyroidism (Fig. 1, Tables I and II), the ratio of $\left[{ }^{125} \mathrm{I}\right] \mathrm{T} 3(\mathrm{~T} 4) /\left[{ }^{131} \mathrm{I}\right] \mathrm{T} 3$ was considered a more accurate reflection of $\mathrm{T} 4$ to $\mathrm{T} 3$ conversion. In agreement with the similar fractional
T4 to T3 conversion rates between euthyroid and hypothyroid rats (Table I), thyroid status did not affect this ratio. In euthyroid rats, PTU pretreatment resulted in a $70 \%(P<0.010)$ and $56 \%$ $(P<0.005)$ reduction in the $\left[{ }^{125} \mathrm{I}\right] \mathrm{T} 3(\mathrm{~T} 4) /\left[{ }^{131} \mathrm{I}\right] \mathrm{T} 3$ ratio at 4 and $22 \mathrm{~h}$, respectively, while it had no effect on this ratio in hypothyroid rats at either time interval. As shown below, PTU at this dosage caused $>90 \%$ inhibition of $5{ }^{\prime} \mathrm{D}-\mathrm{I}$ in liver and kidney.

Demonstration of a PTU-induced reduction in extrathyroidal T3 production after high doses of exogenous T4. Because of the roughly 100 -fold lower apparent $K_{\mathrm{m}}$ of 5'D-II (10-13), and the marked increase in this enzyme in the cerebral cortex, pituitary, and BAT of the hypothyroid rats, the generation of serum T3 after different doses of T4 and the effect of PTU thereon were studied. Rats were injected with 1,2 , or $10 \mu \mathrm{g}$ of $\mathrm{T} 4 / 100 \mathrm{~g}$ bw and serum levels of T4 and T3 were measured by RIA $24 \mathrm{~h}$ later. The results are shown in Table III. The hypothyroid state of the animals is well documented by the low basal levels of serum $\mathrm{T} 4$ and $\mathrm{T} 3$. When $1 \mu \mathrm{g}$ of $\mathrm{T} 4 / 100 \mathrm{~g}$ bw was injected, pretreatment with PTU in various doses did not affect the increment in serum T3. When the dose of T4 was increased, PTU significantly inhibited T4 to T3 conversion. Furthermore, when $10 \mu \mathrm{g} \mathrm{T} 4 / 100 \mathrm{~g}$ bw was injected, the serum T4 concentration was ten times higher than after $1 \mu \mathrm{g}$ was injected, but the increment in T3 was barely two times that found with $1 \mu \mathrm{g}$ T4/ $100 \mathrm{~g} \mathrm{bw}$, which suggested a decreased fractional conversion. The increment in serum $\mathrm{T} 3$ was $\sim 60 \%$ less when rats receiving $10 \mu \mathrm{g} \mathrm{T} 4 / 100 \mathrm{~g}$ bw were pretreated with PTU $(P<0.001)$. Regardless of the dose of T4, PTU in the various dosages reduced liver $5^{\prime} \mathrm{D}-\mathrm{I}$ activity $>85 \%$ and the kidney $5^{\prime} \mathrm{D}-\mathrm{I}$ enzyme was $>90 \%$ inhibited by doses of PTU of $2-6 \mathrm{mg} / 100 \mathrm{~g}$ bw (Table III).

Effect of reverse T3 (rT3) on extrathyroidal T3 production in hypothyroid rats. Since rT3 is a potent inhibitor of $5^{\prime} \mathrm{D}-\mathrm{II}$ in cortex and pituitary and has the advantage that it is rapidly cleared (22), we used this iodothyronine to see the effect of decreasing 5'D-II on $\mathrm{T} 4$ to $\mathrm{T} 3$ conversion in hypothyroid rats. In the experiment shown in Table IV, thyroidectomized rats were given $30 \mu \mathrm{g} \mathrm{rT} 3 / 100 \mathrm{~g} \mathrm{bw}$; the controls were injected with $50 \mathrm{ng} \mathrm{T4} / 100 \mathrm{~g}$ bw. This was the maximum amount of T4 that could contaminate the rT3, based on T4 RIA. At $4 \mathrm{~h}$, when the effect of rT3 on 5'D-II is maximal (22), the serum rT3 concentration is $<2 \mathrm{ng} / \mathrm{ml}$. This was estimated from the concentration of tracer $\left[{ }^{125} \mathrm{I}\right] \mathrm{rT} 3$ that was given together with the unlabeled rT3. At this time, $\left[{ }^{125} \mathrm{I}\right] \mathrm{T} 4$ and $\left[{ }^{131} \mathrm{I}\right] \mathrm{T} 3$ were injected and the rats killed $3 \mathrm{~h}$ afterwards. $7 \mathrm{~h}$ after the injection of $\mathrm{rT3}$, 5'D-II was still significantly inhibited in all three tissues by $>60 \%$ $\left(P<0.05\right.$, Table IV). The serum concentration of $\left[{ }^{125} \mathrm{I}\right] \mathrm{T} 3(\mathrm{~T} 4)$ was significantly reduced, as was the $\left[{ }^{125} \mathrm{I}\right] \mathrm{T} 3(\mathrm{~T} 4) /\left[{ }^{131} \mathrm{I}\right] \mathrm{T} 3$ ratio, but neither $\left[{ }^{125} \mathrm{I}\right] \mathrm{T} 4$ nor $\left[{ }^{131} \mathrm{I}\right] \mathrm{T} 3$ concentrations were affected by the pretreatment with $\mathrm{rT} 3$.

\section{Discussion}

T4 and T3 kinetics and T4 to T3 conversion in hypothyroid rats. The clearance rates of $\mathrm{T} 4$ and $\mathrm{T} 3$ were reduced by $45-$ 
Table I. Major Kinetics Parameters of T4 and T3, and Fractional T4 to T3 Conversion in Adult Euthyroid and Hypothyroid Rats by Single and Noncompartmental Analyses

\begin{tabular}{|c|c|c|c|c|c|}
\hline & & \multicolumn{2}{|c|}{ Euthyroid } & \multirow[b]{2}{*}{ Hypothyroid $(n=36)$} & \multirow[b]{2}{*}{$P$} \\
\hline & & Experiment I $(n=21)$ & Experiment II $(n=36)$ & & \\
\hline Body weight $(g)$ & & $180 \pm 2(\mathrm{SEM})$ & $245 \pm 4$ & $304 \pm 6$ & \\
\hline \multicolumn{6}{|l|}{ Thyroxine } \\
\hline \multirow[t]{2}{*}{$\mathrm{VD}(\mathrm{ml})$} & $\mathrm{NCA}$ & 26.5 & 29.3 & 26.0 & - \\
\hline & SCA & $\begin{array}{l}23.9 \\
(21.9-26.1)\end{array}$ & $\begin{array}{l}29.6 \\
(27.2-32.1)\end{array}$ & $\begin{array}{l}19.8 \\
(19.1-20.4)\end{array}$ & $<0.005$ \\
\hline \multirow[t]{3}{*}{$\lambda\left(h^{-1}\right)$} & $\mathrm{NCA}$ & 0.048 & 0.068 & 0.036 & \\
\hline & SCA & 0.058 & 0.075 & 0.057 & - \\
\hline & & $(0.028-0.088)$ & $(0.045-0.105)$ & $(0.035-0.079)$ & NS \\
\hline \multirow[t]{2}{*}{$\mathrm{Cl}(\mathrm{ml} / \mathrm{h})$} & NCA & 1.27 & 2.0 & 0.9 & - \\
\hline & SCA & 1.38 & 2.2 & 1.2 & - \\
\hline \multicolumn{6}{|l|}{ Triiodothyronine } \\
\hline \multirow[t]{3}{*}{$\mathrm{VD}(m l)$} & NCA & 273.0 & 404.0 & 412.0 & \\
\hline & SCA & 294.0 & 416.0 & 403.0 & - \\
\hline & & $(200-434)$ & $(375-500)$ & $(370-435)$ & NS \\
\hline \multirow[t]{3}{*}{$\lambda\left(h^{-1}\right)$} & NCA & 0.121 & 0.118 & 0.055 & - \\
\hline & SCA & 0.115 & 0.121 & 0.075 & $<0.001$ \\
\hline & & $(0.057-0.173)$ & $(0.0078-0.163)$ & $(0.040-0.110)$ & \\
\hline \multirow[t]{2}{*}{$\mathrm{Cl}(\mathrm{ml} / \mathrm{h})$} & NCA & 33.4 & 47.6 & 22.8 & - \\
\hline & SCA & 34.0 & 51.1 & 30.3 & - \\
\hline \multicolumn{6}{|l|}{$\mathrm{T} 4$ to $\mathrm{T} 3$ conversion } \\
\hline (\% of T4 disposed)‡ & NCA & 22.0 & 21.5 & 25.6 & - \\
\hline (\% of T4 disposed/d)‡ & NCA & 15.0 & 17.0 & 15.0 & - \\
\hline
\end{tabular}

$n$, number of pairs used to calculate the regression lines in the single compartment analyses. NCA, noncompartmental analyses; SCA, single compartmental analyses; VD, volume of distribution; $\lambda$, fractional removal rate; and $\mathrm{Cl}$, clearance. All serum concentrations were normalized to $200 \mathrm{~g}$ bw (see Methods); therefore, VD and $\mathrm{Cl}$ correspond to a $200 \mathrm{~g}$ rat. Rats were injected with $\left[{ }^{125} \mathrm{I}\right] \mathrm{T} 4$ and $\left[{ }^{131} \mathrm{I}\right] \mathrm{T} 3$ into the external jugular vein, and bled at different times after the injections by cardiac puncture under light ether anesthesia. Bleedings were performed as follows: Blood sample collection (see Methods): Experiment I: Three groups of three rats each, A, B, and C, were bled with the following schedule: A at 1, 12, and $24 \mathrm{~h} ; \mathrm{B}$ at 9 and $20 \mathrm{~h}$; and $\mathrm{C}$ at 4 and $15 \mathrm{~h}$. Experiment II: Four groups of four rats each, A, B, C, and D were bled with the following schedule: A at 2, 8, and $24 \mathrm{~h} ; \mathrm{B}$ at 4 and $12 \mathrm{~h} ; \mathrm{C}$ at 6 and $18 \mathrm{~h}$; and D at 15 and $20 \mathrm{~h}$. Hypothyroid rats: Four groups of four rats each, A, B $C$, and D, were bled with the following schedule: $A$ at $0.5,6$, and $24 \mathrm{~h} ; B$ at 1 and $8 \mathrm{~h} ; C$ at 2 and $12 \mathrm{~h}$; and D at 4 and $16 \mathrm{~h}$. ${ }^{*}$ Statistical analyses. The probability of significance is given only for parameters calculated by SCA; the figures in parentheses indicate the $95 \%$ confidence limits. Since parameters obtained by SCA are composite figures, i.e., obtained from curves generated by the means of independent observations, no statistical analyses are possible. ‡ Based on our method of analysis, fractional conversion of T4 to T3 means percentage of total [125I]T4 disposed of converted to $\left[{ }^{125} \mathrm{I}\right] \mathrm{T} 3$, with no time frame. The lower figures have taken into consideration that the total residence time of [ $\left.{ }^{125} \mathrm{I}\right] \mathrm{T} 4$ in the hypothyroid rats is prolonged. The figures have been obtained by multiplying the total conversion rates above by the fraction of [125I]T4 metabolized per day, $1-\mathrm{e}^{-\lambda_{4} \times 24}$, where $\lambda_{4}$ is the fractional removal rate of $\mathrm{T} 4$ in hours ${ }^{-1}$.

$50 \%$ (Table I) in hypothyroid rats. Although it was not possible to assess directly the statistical significance of this reduction, the magnitude of it and the variance of the primary data (Fig. 1) suggest that the clearances are significantly different. The reduction may reflect the combined effect of the generalized slowing of many metabolic processes in this condition, the spe- cific decrease in the hepatic and renal iodothyronine degradation observed in this state (24-26), and the increase in plasma binding of iodothyronines observed in hypothyroidism. Thus, in seven pairs of samples taken randomly from rats used in these experiments, the dialyzable fraction of $\mathrm{T} 4$ was reduced to $60 \pm 3.6 \%$ and that of $\mathrm{T} 3$ to $74 \pm 3 \%$ of the corresponding values found in 


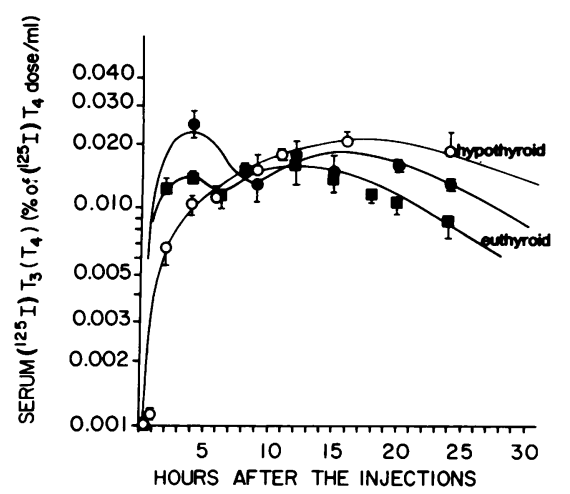

Figure 2. Time course of appearance of $\left[{ }^{125} \mathrm{I}\right] \mathrm{T} 3$ in the serum after injecting [ $\left.{ }^{125} \mathrm{I}\right] \mathrm{T} 4$ into euthyroid and hypothyroid rats. These results are from the same rats shown in Fig. 1 and symbols and explanations are the same. The serum concentrations of $\left[{ }^{125} \mathrm{I}\right] \mathrm{T} 3(\mathrm{~T} 4)$ have also been normalized to $200 \mathrm{~g}$ bw. The contributions of contaminating [25I]T3 in the [ ${ }^{125}$ I]T4 dose to each time point have been subtracted and the residual [ $\left.{ }^{125} \mathrm{I}\right] \mathrm{T} 3$ activity multiplied by two to correct for the loss of specific activity during T4 to T3 conversion.

the euthyroid sera $\left(\mathrm{T} 4=[5.3 \pm 0.9] \times 10^{-4}\right.$ and $\mathrm{T} 3=[47 \pm 5]$ $\left.\times 10^{-4} ; P>0.001\right)$.

The pattern of appearance of $\left[{ }^{125} \mathrm{I}\right] \mathrm{T} 3(\mathrm{~T} 4)$ in plasma was different in euthyroid from that in hypothyroid rats (Fig. 2).
While in the latter there was a slow rate of accumulation, in the former there was an early peak of $\left.{ }^{125} \mathrm{I}\right] \mathrm{T} 3(\mathrm{~T} 4)$ followed by a broader wave of $\left.{ }^{125} \mathrm{I}\right] \mathrm{T} 3(\mathrm{~T} 4)$ accumulation. In agreement with this observation, Table II shows that $4 \mathrm{~h}$ after the $\left[{ }^{125} \mathrm{I}\right] \mathrm{T} 4 \mathrm{in}$ jection serum $\left[{ }^{125} \mathrm{I}\right] \mathrm{T} 3$ was greater than at $22 \mathrm{~h}$ in euthyroid rats, whereas the opposite was observed in hypothyroid rats. We have made the same observation in 2-wk-old euthyroid rats (Silva, J. E., submitted for publication) and observed the same pattern when sequential bleedings have been analyzed in individual euthyroid rats (not shown). Although we do not have a definitive explanation for this phenomenon, we postulate that the early peak represents a rather large amount of $\left[{ }^{125} \mathrm{I}\right] \mathrm{T} 3(\mathrm{~T} 4)$ rapidly transferred into the circulation, formed in pools like liver and kidney that exchange T3 rapidly with plasma (2729). The appearance of this peak is probably related to several features such as the bolus nature of the injection, the characteristics of the uptake of $\left.{ }^{125} \mathrm{I}\right] \mathrm{T} 4$ by liver and kidney, the rate of conversion to $\left.{ }^{125} \mathrm{I}\right] \mathrm{T} 3(\mathrm{~T} 4)$, and the rate of transfer of this T3 into the circulation. Since the technique of the tracers injections was the same in all experiments, the absence of the peaks in hypothyroid rats has to be related to the other factors, one of which, the decreased T4 5'-diodinating activity of the liver and kidney, is well documented (24-26). However, we do wish to imply that the magnitude of this peak represents the total contribution of these rapid compartments to serum T3(T4), since the influx of $\left[{ }^{125} \mathrm{I}\right] \mathrm{T} 3(\mathrm{~T} 4)$ from these sources will continue

Table II. Effects of PTU and Thyroid Status on $\left[{ }^{125} I\right] T 4,\left[{ }^{125} I\right] T 3(T 4)$, and $\left[{ }^{131} I\right] T 3$ Serum Concentrations in Adult Euthyroid and Hypothyroid Rats Given $\left[{ }^{125} I\right] T 4$ and $\left[{ }^{131} I\right] T 3$

\begin{tabular}{|c|c|c|c|c|c|c|c|}
\hline \multirow[t]{2}{*}{ Time after tracers } & & \multicolumn{3}{|c|}{$4 \mathrm{~h}$} & \multicolumn{3}{|c|}{$22 \mathrm{~h}$} \\
\hline & & -PTU & + PTU & $P$ & -PTU & + PTU & $P$ \\
\hline \multirow[t]{3}{*}[{}^{125}\mathrm{I}]{$\mathrm{T} 4$} & Euthyroid & $3.1 \pm 0.1$ & $3.0 \pm 0.1$ & NS & $1.0 \pm 0.0$ & $1.2 \pm 0.0$ & $<0.05$ \\
\hline & Hypothyroid & $4.2 \pm 0.2$ & $4.0 \pm 0.1$ & NS & $1.8 \pm 0.1$ & $1.8 \pm 0.1$ & NS \\
\hline & $P$ & $<0.001$ & $<0.005$ & & $<0.005$ & $<0.001$ & \\
\hline \multirow[t]{3}{*}[{}^{131}\mathrm{I}]{$\mathrm{T} 3$} & Euthyroid & $0.16 \pm 0.00$ & $0.14 \pm 0.01$ & NS & $(13 \pm 0) \times 10^{-3}$ & $(18 \pm 2) \times 10^{-3}$ & NS \\
\hline & Hypothyroid & $0.26 \pm 0.01$ & $0.30 \pm 0.01$ & $<0.05$ & $0.05 \pm 0.00$ & $0.08 \pm 0.00$ & $<0.010$ \\
\hline & $P$ & $<0.001$ & $<0.001$ & & $<0.001$ & $<0.001$ & \\
\hline \multirow[t]{3}{*}[{}^{125}\mathrm{I}]{$\mathrm{T} 3(\mathrm{~T} 4)\left(\times 10^{3}\right)$} & Euthyroid & $16.0 \pm 2.4$ & $4.2 \pm 0.7$ & $<0.005$ & $6.4 \pm 0.4$ & $3.6 \pm 0.7$ & $<0.025$ \\
\hline & Hypothyroid & $18.7 \pm 2.2$ & $24.6 \pm 3.3$ & NS & $24.5 \pm 4.1$ & $31.8 \pm 2.6$ & NS \\
\hline & & NS & $<0.001$ & & $<0.005$ & $<0.001$ & \\
\hline \multirow{4}{*}{$\left(\frac{\left[\left[^{125} \mathrm{I}\right] \mathrm{T} 3\right.}{\left[{ }^{131} \mathrm{I}\right] \mathrm{T} 3}\right)\left(\times 10^{2}\right)$} & & & & & & & \\
\hline & Euthyroid & $10.5 \pm 1.7$ & $3.1 \pm 0.5$ & $<0.010$ & $48.7 \pm 4.9$ & $21.0 \pm 2.8$ & $<0.005$ \\
\hline & Hypothyrnid & $7.0 \pm 0.7$ & $8.4 \pm 1.2$ & NS & $45.0 \pm 5.1$ & $42.4 \pm 3.7$ & NS \\
\hline & & NS & $<0.010$ & & NS & $<0.005$ & \\
\hline
\end{tabular}

Each cell is the mean \pm SEM of four rats. All concentrations are expressed as percentage of the dose per milliliter. $\left.{ }^{125}{ }^{12}\right] \mathrm{T} 3$ (T4), the T3 produced from T4, has been corrected for the contaminating $\left[{ }^{125} \mathrm{I}\right] \mathrm{T} 3$ in the $\left[{ }^{125} \mathrm{I}\right] \mathrm{T} 4(0.75 \%)$ and for the $50 \%$ decrease in specific activity during T4 to T3 conversion. It is expressed as percentage of the [ ${ }^{125}$ I]T4 dose per milliliter. The effect of PTU and thyroid status on each parameter was analyzed by two-way analysis of variance. 
Table III. Effect of PTU on Serum T3 24 H after Injecting Various Doses of T4 to Tx Adult Rats (MeantSE)

\begin{tabular}{|c|c|c|c|c|c|c|c|c|c|c|c|c|c|}
\hline \multirow[b]{2}{*}{ Expt. } & \multirow[b]{2}{*}{$\mathbf{N}$} & \multicolumn{2}{|c|}{ Treatment (dose) } & \multicolumn{6}{|c|}{ Serum concentrations } & \multicolumn{4}{|c|}{ Type I 5'-deiodinase activity } \\
\hline & & $\mathrm{T}^{*}$ & PTU $\ddagger$ & T4 & & T3 & & & & Liver & & Kidney & \\
\hline & & $g / 100 g b w$ & $m g / 100 g b w$ & $n g / m l$ & & $n g / m l$ & & & & $\%$ control & & \% control & \\
\hline & & & & Basal§ & Post & Basal & Post & $\Delta$ & $P$ & & & & \\
\hline \multirow[t]{4}{*}{ I } & 4 & 1 & 0 & $0.3 \pm 0.1$ & $37 \pm 3.0$ & $0.27 \pm 0.05$ & $0.58 \pm 0.08$ & $0.31 \pm 0.05$ & $<0.005$ & $100 \pm 17$ & & $100 \pm 14$ & \\
\hline & 4 & 1 & 1 & $0.2 \pm 0.1$ & $34 \pm 2.0$ & $0.24 \pm 0.07$ & $0.50 \pm 0.08$ & $0.26 \pm 0.04$ & $<0.01$ & $9 \pm 1$ & $<0.005$ & $31 \pm 7$ & $<0.005$ \\
\hline & 4 & 1 & 2 & $0.2 \pm 0.0$ & $37 \pm 2.1$ & $0.17 \pm 0.03$ & $0.58 \pm 0.06$ & $0.41 \pm 0.05$ & $<0.005$ & $10 \pm 4$ & $<0.005$ & $7 \pm 5$ & $<0.001$ \\
\hline & & & & & & & & NS & & & & & \\
\hline \multirow[t]{3}{*}{ II } & 4 & 1 & 0 & $0.0 \pm 0.0$ & $40 \pm 5.0$ & $0.06 \pm 0.01$ & $0.36 \pm 0.06$ & $0.30 \pm 0.06$ & $<0.025$ & $100 \pm 14$ & & $100 \pm 2$ & \\
\hline & 4 & 1 & 6 & $0.3 \pm 0.3$ & $40 \pm 8.0$ & $0.04 \pm 0.01$ & $0.36 \pm 0.09$ & $0.31 \pm 0.09$ & $<0.05$ & $0 \pm 0$ & $<0.001$ & $2 \pm 3$ & $<0.001$ \\
\hline & & & & & & & & NS & & & & & \\
\hline \multirow[t]{3}{*}{ III } & 4 & 2 & 0 & $2.2 \pm 1.0$ & $57 \pm 7.6$ & $0.33 \pm 0.05$ & $0.49 \pm 0.04$ & $0.16 \pm 0.02$ & $<0.005$ & $100 \pm 19$ & & - & \\
\hline & 4 & 2 & 4 & $0.8 \pm 0.5$ & $58 \pm 3.1$ & $0.33 \pm 0.06$ & $0.34 \pm 0.04$ & $0.01 \pm 0.03$ & NS & $4 \pm 0.6$ & $<0.001$ & - & \\
\hline & & & & & & & & $<0.005$ & & & & & \\
\hline \multirow[t]{3}{*}{ IV } & 4 & 10 & 0 & $0.0 \pm 0.0$ & $380 \pm 18$ & $0.00 \pm 0.02$ & $0.60 \pm 0.06$ & $0.60 \pm 0.06$ & $<0.001$ & $100 \pm 19$ & & - & \\
\hline & 6 & 10 & 6 & $0.0 \pm 0.0$ & $410 \pm 14$ & $0.03 \pm 0.02$ & $0.29 \pm 0.03$ & $0.26 \pm 0.04$ & $<0.001$ & $14 \pm 1$ & $<0.001$ & - & \\
\hline & & & & & & & & $<0.001$ & & & & & \\
\hline
\end{tabular}

* In experiment I, T4 was given intraperitoneally; in experiments II-IV, T4 was injected intravenously. ‡ PTU was always injected intraperitoneally. In experiments I and III, the total dose was injected $\sim 1 \mathrm{~h}$ preceding the T4, and in experiments II and IV it was injected in three doses of $2 \mathrm{mg} / 100 \mathrm{~g}$ bw each at 6,4 , and $2 \mathrm{~h}$ before the T4 dose. $\S$ Basal serum T4 was not significantly different from zero in all groups.

thereafter and mix with $\left[{ }^{125} \mathrm{I}\right] \mathrm{T} 3(\mathrm{~T} 4)$ that appears in the circulation from other sources.

The magnitude of fractional conversion in euthyroid rats, $22 \%$ of the [ $\left.{ }^{125} \mathrm{I}\right] \mathrm{T} 4$ disposed of, is in agreement with figures previously reported by others in euthyroid rats $(3,28,29)$. However, based on previous data showing a decreased rate of $\mathrm{T} 4$ disappearance in hypothyroid rats (30), as confirmed here, and based on the well documented decreased iodothyronine 5'deiodinase activity in hypothyroid liver and kidney (24-26), the finding of $26 \%$ of the $\left[{ }^{125} \mathrm{I}\right] \mathrm{T} 4$ converted to $\mathrm{T} 3$ in hypothyroid rats was surprising. Even when the decreased rate of metabolism of T4 in these rats is taken into consideration, the fraction of $\left[{ }^{125} \mathrm{I}\right] \mathrm{T} 4$ converted to $\left[{ }^{125} \mathrm{I}\right] \mathrm{T} 3$ per day is not different from that calculated for the hypothyroid rats (Table I). This indicates that the slower rate of disappearance of $\mathrm{T} 4$ in hypothyroid rats is due to a decreased rate of metabolism by pathways other than 5 '-deiodination, and suggests, as discussed below, that there is a shift in the source of extrathyroidal $\mathrm{T} 3$ production as a consequence of hypothyroidism.

Failure of PTU to reduce T4 to T3 conversion in hypothyroid rats. PTU in dosage regimens similar to the ones used in these experiments reduces extrathyroidal T4 to T3 conversion in euthyroid rats by $60-70 \%(9,12)$, as corroborated in the present experiments (Table II). This incomplete inhibition suggests that even in euthyroid rats, a fraction of the extrathyroidally produced serum T3 may be generated via a PTU-insensitive pathway. Since 5'D-II activity is increased in hypothyroidism and is insensitive to PTU, conversion by this enzyme certainly could explain the shift of the source of extrathyroidally generated $\mathrm{T} 3$ from a predominantly 5 'D-I pathway in euthyroidism to a predominantly 5 'D-II one in the hypothyroid state.

In hypothyroid rats, $2 \mathrm{mg}$ PTU/100 $\mathrm{g}$ bw inhibited liver and kidney 5'D-I $>90 \%$ for $24 \mathrm{~h}$ (Table III). Despite this inhibition, extrathyroidal T3 generation was not affected. Increasing the dose to as much as $6 \mathrm{mg}$ PTU/100 $\mathrm{g}$ bw in three doses before the injection of $\mathrm{T} 4 \mathrm{did}$ not decrease the increment in serum T3 after a $1 \mu \mathrm{g} / 100 \mathrm{~g}$ bw dose of T4 (Table III, experiment II). These results suggest that $2 \mathrm{mg}$ PTU/100 $\mathrm{g}$ bw is a maximal dose in vivo.

Effect of the dose of T4 on T4 to T3 conversion rates and on the sensitivity to PTU in hypothyroidism. The similar fractional $\left[{ }^{125} \mathrm{I}\right] \mathrm{T} 4$ to $\left[{ }^{125} \mathrm{I}\right] \mathrm{T} 3$ conversion in euthyroid and hypothyroid rats may be related to the higher specific activity of the tracers in the rats lacking endogenous $\mathrm{T} 4$. On the other hand, 5'D-II has a low apparent $K_{\mathrm{m}}$ for T4 and is rapidly suppressed by $\mathrm{T} 4, \mathrm{~T} 3$, and $\mathrm{rT} 3$ (22). It was therefore conceivable that by giving T4 in higher doses, 5'D-II would be reduced and PTU would become effective in reducing the rate of fractional conversion due to recruitment of the higher $K_{\mathrm{m}}$, PTU-sensitive 5'DI pathway. The experiment in Table III shows that after $1 \mu \mathrm{g}$ 
Table IV. Effects of rT3 on Type II 5'-Deiodinase Activity in Various Tissues, and on $\left[{ }^{125} I\right] T 4$ to $\left[{ }^{125} I\right] T 3$ Conversion in Tx (Mean $\pm S E)^{*}$

\begin{tabular}{|c|c|c|c|c|}
\hline Treatment & & Control & $\mathrm{rT3}$ & $P$ \\
\hline \multicolumn{5}{|c|}{ Type II $5^{\prime}$-deiodinase $(\mathrm{fmol} / \mathrm{h} / \mathrm{mg}$ prot $)$} \\
\hline Tissue & Subs & & & \\
\hline \multirow[t]{2}{*}{ Cortex } & rT3 & $106 \pm 11$ & $20 \pm 1$ & $<0.001$ \\
\hline & T4 & $96 \pm 8$ & $20 \pm 1$ & $<0.001$ \\
\hline Pituitary & rT3 & $714 \pm 50$ & $120 \pm 21$ & $<0.001$ \\
\hline BAT & rT3 & $242 \pm 49$ & $91 \pm 20$ & $<0.05$ \\
\hline \multicolumn{5}{|c|}{ Variables reflecting in vivo $\left[{ }^{125} \mathrm{I}\right] \mathrm{T} 4$ to $\left[{ }^{125} \mathrm{I}\right] \mathrm{T} 3$ conversion } \\
\hline \multicolumn{5}{|l|}{ Iodothyronines§ } \\
\hline$\left[{ }^{125} \mathrm{I}\right] \mathrm{T} 4$ & & $3.3 \pm 0.5$ & $3.2 \pm 0.4$ & NS \\
\hline$\left[{ }^{125} \mathrm{I}\right] \mathrm{T} 3\left(\times 10^{-3}\right)$ & & $12 \pm 1$ & $6 \pm 1$ & $<0.01$ \\
\hline$\left[{ }^{131} 1\right] \mathrm{T} 3$ & & $0.21 \pm 0.02$ & $0.21 \pm 0.02$ & NS \\
\hline$\frac{\left[{ }^{125} \mathrm{I}\right] \mathrm{T} 3}{1{ }^{13}+15^{3}} \times 15^{3}$ & & & & \\
\hline$\left[{ }^{131} \mathrm{I}\right] \mathrm{T} 3 \times 10$ & & $55 \pm 4$ & $28 \pm 4$ & $<0.005$ \\
\hline
\end{tabular}

* Chronic Tx were injected with $30 \mu \mathrm{g} / 100 \mathrm{~g}$ bw of rT3. Controls were given $50 \mathrm{ng} / 100 \mathrm{~g}$ bw T4 (the maximal amount of T4 possible as a rT3 contaminant). $4 \mathrm{~h}$ later the animals were injected with $\left[{ }^{125} \mathrm{I}\right] \mathrm{T} 4$ and $\left[{ }^{131} \mathrm{I}\right] \mathrm{T} 3$ and killed $3 \mathrm{~h}$ afterwards. Type II $5^{\prime}$-deiodinase was measured as described in Methods in homogenates of the indicated tissues. Either rT3 in the presence of $1 \mathrm{mM}$ PTU or T4 were used as substrates. Labeled iodothyronines in cortex and serum were separated as described in Methods. The concentrations of [ $\left.{ }^{125} \mathrm{I}\right] \mathrm{T} 3$ have been corrected for the amount of $\left[{ }^{125} \mathrm{I}\right] \mathrm{T} 3$ contaminating $\left[{ }^{125} \mathrm{I}\right] \mathrm{T} 4(0.1 \%)$ and for the $50 \%$ decrease in specific activity of [ $\left.{ }^{125} \mathrm{I}\right] \mathrm{T} 3$ during $\mathrm{T} 4$ to $\mathrm{T} 3$ conversion.

¥ Both substrates were used at $2 \mathrm{nM}$ in the enzyme assay. $\S$ All concentrations are expressed as percentage of dose of the injected tracer per milliliter of serum.

T4/100 $\mathrm{g}$ bw, PTU did not reduce the formation of T3, but when the dose was increased, PTU did become effective. Furthermore, at $10 \mu \mathrm{g} \mathrm{T} 4 / 100 \mathrm{~g}$ bw there was a substantial fall in fractional T4 to T3 conversion. These results suggest that the mechanism producing $\mathrm{T} 3$ from $\mathrm{T} 4$ in hypothyroid rats is easily saturated or suppressed at T4 doses higher than the euthyroid daily production rate of $1 \mu \mathrm{g} / 100 \mathrm{~g}$. Since over this dose range fractional conversion is decreased and becomes inhibitable by PTU, we can conclude that at up to physiological replacement doses, $5^{\prime} \mathrm{D}$-II is the predominant pathway in hypothyroid rats, and that only upon saturation or suppression of $5 \mathrm{D}$-II is the 5'D-I pathway made evident.

Effects of inhibiting $5^{\prime} D-I I$ upon $\left[{ }^{125} I\right] T 3$ generation from $\left.{ }^{125} \Pi\right] T 4$. Since cortex and pituitary 5 'D-II is rapidly and markedly inhibited by reverse T3 (22), we used this iodothyronine to decrease the activity of 5 'D-II. In agreement with the reduction in 5 D-II activity, [ $\left.{ }^{125} \mathrm{I}\right] \mathrm{T} 3$ accumulation was reduced in the serum. This contrasts with the lack of effect of PTU, which inhibits $5^{\prime} \mathrm{D}-\mathrm{I}$ by $>90 \%$, and is therefore consistent with our hypothesis that 5 D-II is a major source of $\left[{ }^{125} \mathrm{I}\right] \mathrm{T} 3(\mathrm{~T} 4)$ in hypothyroid rats.

Leonard and Rosenberg (31) have reported an early phase in $5^{\prime}$-deiodination in kidney membranes $\left(5^{\prime} \mathrm{D}-\mathrm{I}\right)$ that is PTUinsensitive and thiol-independent. This phase, which lasts only a few seconds, is thought to be due to the presence of small quantities of enzyme with the active thiol groups in reduced form. Once the enzyme interacts with the substrates, T4 or rT3, sulfenyliodides are formed and PTU interacts with them, forming mixed disulfide bonds and inactivating the enzyme. It is then conceivable that our results are due to this phenomenon; because of the lack of substrate in hypothyroid rats, most of the enzyme is in reduced form and, therefore, a substantial degree of $5^{\prime}$ deiodination ensues before the enzyme becomes sensitive to PTU. The results of the experiment just described, in which rats were pretreated with $\mathrm{rT} 3$, along with the lack of effect of PTU after $1 \mu \mathrm{g}$ of T4/100 $\mathrm{g}$ bw (Table III) and the time course of $\left[{ }^{125} \mathrm{I}\right] \mathrm{T} 3$ appearance after $\left[{ }^{125} \mathrm{I}\right] \mathrm{T} 4$ in hypothyroid PTU-treated rats (Table II), altogether make this potential explanation extremely unlikely.

Of the three tissues known to contain 5'D-II, the brown adipose tissue is the most likely to be an important source of serum T3, since it is well perfused (32) and relatively abundant in the rat (33). Assessment of the contribution of BAT 5'D-II to plasma $\mathrm{T} 3$ is presently under investigation. Although our efforts to demonstrate 5'D-II in other tissues (liver, kidney, muscle, heart) have been unsuccessful, its presence in low concentrations in these larger organs or tissues has to be kept in mind. Wherever the enzyme is located, the combined results with PTU and rT3 indicate that 5'D-II can serve as a source of plasma as well as of intercellular T3. It is clearly the major source of extrathyroidally produced $\mathrm{T} 3$ in the hypothyroid rat, and probably a significant source in the enthyroid animal as well.

Physiological implications of these studies for man. Our findings are in agreement with observations by Morris et al. (34) that suggest increased fractional T4 to T3 conversion in hypothyroxinemic humans, and with the earlier observations of Inada et al. (35) indicating normal or increased fractional $\mathrm{T} 4$ to $\mathrm{T} 3$ conversion in hypothyroidism in man. In addition, these results provide a physiological rationale for the initial therapy of hypothyroid patients with comparatively small amounts of T4 $(\sim 100 \mu \mathrm{g} / 24 \mathrm{~h})(36)$ rather than T3 (37) or larger doses of T4 (38), until the liver and kidney recover their capacity to catalyze T4 to T3 conversion. Such doses of T4 would maintain a more efficient $\mathrm{T} 4$ to $\mathrm{T} 3$ conversion and, equally important, would facilitate production of T3 in the cerebral cortex, where, at least in the rat, $\sim 75 \%$ of the T3 is produced locally in a reaction catalyzed by 5 'D-II (39). A large dose of T4 (or T3) would inhibit the cerebrocortical 5'D-II and would impair local T3 generation in this tissue (22), and might decrease the overall fractional conversion in a situation where most of serum T3 may be generated by 5 'D-II. 


\section{Appendix 1}

Table V. Calculation of Serum $\left[{ }^{125} I\right] T 3$ Produced from $\left[{ }^{125} I\right] T 4$ : Example on Three Serum Samples from Individual Rats*

\begin{tabular}{|c|c|c|c|}
\hline & \multicolumn{3}{|c|}{$\begin{array}{l}\text { Hours after injections } \\
\text { (all } \mathrm{cpm} / \mathrm{ml} \text { of serum) } \ddagger\end{array}$} \\
\hline & 2 & 15 & 24 \\
\hline Total ${ }^{125} \mathbf{I}$ & $1,820,000$ & 823,000 & 615,000 \\
\hline Total ${ }^{131} \mathbf{I}$ & 106,000 & 61,500 & 17,300 \\
\hline$\left[{ }^{125} \mathrm{I}\right] \mathrm{T} 4$ & $1,260,000$ & 471,000 & 400,000 \\
\hline$\left[{ }^{131} \mathrm{I}\right] \mathrm{T} 3$ & 45,900 & 12,500 & 2,620 \\
\hline \multicolumn{4}{|c|}{ After affinity chromatography§: } \\
\hline$\left[{ }^{125} \mathrm{I}\right] \mathrm{T} 3$ & 291 & 980 & 354 \\
\hline$\left[{ }^{131} 1\right] T 3$ & 5,530 & 2,420 & 550 \\
\hline$\left[{ }^{125} \mathrm{I}\right] \mathrm{T} 4$ & 432 & 699 & 158 \\
\hline
\end{tabular}

Dose [ $\left.{ }^{125} \mathrm{I}\right] \mathrm{T} 4$ ([ $\left.\left.{ }^{125} \mathrm{I}\right] \mathrm{T} 4 \mathrm{D}\right) / 64,000,000 \mathrm{cpm}$. Dose [ $\left.{ }^{131} \mathrm{I}\right] \mathrm{T} 3\left(\left[{ }^{131} \mathrm{I}\right] \mathrm{T} 3 \mathrm{D}\right) /$ $34,000,000 \mathrm{cpm}$. *2- and 24-h samples belong to rat No. 1, $260 \mathrm{~g}$ bw; 15-h sample belongs to rat No. 12, $228 \mathrm{~g}$ bw. ‡ All samples counted to $\leq 1 \%$ counting error. $\S$ Crude $\mathrm{cpm} / \mathrm{ml}$ of serum in paper chromatograms of methanol/NH4-eluates from Sepharose-T3Ab columns.

$\left.{ }^{125} \mathrm{I}\right] \mathrm{T} 3$ (percentage of $\left[{ }^{125} \mathrm{I}\right] \mathrm{T} 4$ dose per milliliter $\times 10^{3}$ )

$$
\begin{aligned}
2 \mathrm{~h} & =\left(291 \div \frac{5,530}{45,900} \div\left[{ }^{125} \mathrm{I}\right] \mathrm{T} 4 \mathrm{D}\right) \times 100 \times 10^{3}=3.78 . \\
15 \mathrm{~h} & =\left(980 \div \frac{2,420}{12,500} \div\left[{ }^{125} \mathrm{I}\right] \mathrm{T} 4 \mathrm{D}\right) \times 100 \times 10^{3}=7.90 . \\
24 \mathrm{~h} & =\left(354 \div \frac{550}{2,620} \div\left[{ }^{125} \mathrm{I}\right] \mathrm{T} 4 \mathrm{D}\right) \times 100 \times 10^{3}=2.64
\end{aligned}
$$

Other corrections were $(a)$ the $\left[{ }^{125} \mathrm{I}\right] \mathrm{T} 3$ contaminating the $\left[{ }^{125} \mathrm{I}\right] \mathrm{T} 4$ dose, $0.25 \%$ of the [125I]T4 counts in this experiment: $64,000,000 \times 0.0025$ $=160,000 \mathrm{cpm}$ injected $\left[{ }^{125} \mathrm{I}\right] \mathrm{T} 3 ;(b)$ correction for loss of specific activity during 5'-deiodination (multiply by two); (c) normalization to $200 \mathrm{~g}$ bw.

$$
\begin{aligned}
2 \mathrm{~h} & =\left(3.78-\frac{160,000}{\left[{ }^{125} \mathrm{I}\right] \mathrm{T} 4 \mathrm{D}} \times \frac{45,900 \times 100}{\left[{ }^{131} \mathrm{I}\right] \mathrm{T} 3 \mathrm{D}} \times 10^{3}\right) \times 2 \times \frac{260}{200} \\
& =8.95 \% / \mathrm{ml}\left(\times 10^{3}\right) . \\
15 \mathrm{~h} & =\left(7.90-\frac{160,000}{\left[{ }^{125} \mathrm{I}\right] \mathrm{T} 4 \mathrm{D}} \times \frac{12,500 \times 100}{\left[{ }^{131} \mathrm{I}\right] \mathrm{T} 3 \mathrm{D}} \times 10^{3}\right) \times 2 \times \frac{228}{200} \\
& =17.80 \% / \mathrm{ml}\left(\times 10^{3}\right) . \\
24 \mathrm{~h} & =\left(2.64-\frac{160,000}{\left[{ }^{125} \mathrm{I}\right] \mathrm{T} 4 \mathrm{D}} \times \frac{2,620 \times 100}{\left[{ }^{131} \mathrm{I}\right] \mathrm{T} 3 \mathrm{D}} \times 10^{3}\right) \times 2 \times \frac{260}{200} \\
& =6.81 \% / \mathrm{ml}\left(\times 10^{3}\right) .
\end{aligned}
$$

\section{Appendix II}

Integration of serum [ $\left.{ }^{125} \mathrm{I}\right] \mathrm{T} 3(\mathrm{~T} 4)$ concentrations from $24 \mathrm{~h}$ to infinity after the injections.

The amount of $\left.{ }^{125} \mathrm{I}\right] \mathrm{T} 3(\mathrm{~T} 4)$ at anytime $(t)$ in the system, (QT34) $t$, expressed as a fraction of the [ $\left.{ }^{125} \mathrm{I}\right] \mathrm{T} 4 \mathrm{dose}$ can be defined by (3):

$$
(\mathrm{QT} 34) t=\left(\mathrm{CR} \lambda_{4} / \lambda_{3}-\lambda_{4}\right)\left(\mathrm{e}^{-\lambda_{A} t}-\mathrm{e}^{-\lambda_{3} t}\right) . \quad(\text { Equ.I })
$$

Table VI. Integrated serum $\left[{ }^{125} I\right] T 3(T 4)$ and $\left[{ }^{131} I\right] T 3$ Concentrations in Hypothyroid Rats ([Percentage of Doses Per Milliliter] $\times \mathrm{H}$ )

\begin{tabular}{cll}
\hline Time period & {$\left[{ }^{125} \mathrm{I}\right] \mathrm{T} 3(\mathrm{~T} 4)$} & {$\left[{ }^{131} \mathrm{I}\right] \mathrm{T} 3$} \\
\hline $0-24 \mathrm{~h}$ & 0.38 & 3.23 \\
$24-\infty$ & 0.59 & 1.15 \\
$24-\infty$ corrected & 0.74 & $=$ \\
$0-\infty$ & 1.12 & 4.38 \\
\hline
\end{tabular}

Conversion $($ percentage $)=(1.12 \div 4.38) \times 100=25.6 \%$.

Where CR is the conversion ratio, that is the fraction of the [ $\left.{ }^{125} I\right] T 4$ disappearing in any given interval that has been converted to [ $\left.{ }^{125} \mathrm{I}\right] \mathrm{T} 3$. This equation predicts that the apparent rate of disappearance of QT34 will eventually approach that of T4 at some time after the level of QT34 has reached a maximum. This time will depend on the difference between $\lambda_{3}$ and $\lambda_{4}$ and on their absolute values. In euthyroid rats (Figs. 1 and 2 , and Table I) the concentration of [ ${ }^{125}$ I]T3(T4) in the serum after $24 \mathrm{~h}$ decreases at a rate not markedly different from $\lambda_{4}$. The error resulting from dividing the serum concentration at $24 \mathrm{~h}$ by $\lambda_{4}$ to calculate the integrated concentration from $24 \mathrm{~h}$ to infinity is thus minimal. In contrast, it is apparent from Fig. 2 and from the magnitude of $\lambda_{4}$ and $\lambda_{3}$ (Table I), that such an approach might underestimate the integrated concentration of [ $\left.{ }^{125} \mathrm{I}\right] \mathrm{T} 3$ (T4) after $24 \mathrm{~h}$ in the hypothyroid rats. From Equ. 1 we see that a plot of $\left(\mathrm{e}^{-\lambda_{4} t}-\mathrm{e}^{-\lambda_{3} t}\right)$ vs. time will describe the approximation of the rate of reduction in the serum level of $\left[{ }^{125} \mathrm{I}\right] \mathrm{T} 3(\mathrm{~T} 4)$ to $\lambda_{4}$. By taking the same 24-h serum [ $\left.{ }^{125} \mathrm{I}\right] \mathrm{T} 3$ (T4) value and allowing it to disappear at a rate of $\lambda_{4}$, one obtains the time course of reduction of [ $\left.{ }^{125} \mathrm{I}\right] \mathrm{T} 3$ (T4) decaying at a rate that is not different from that of serum T4. The integration of both curves to infinity allows one to determine the magnitude of any error made by using $\lambda_{4}$ in the hypothyroid rats. The results of such a procedure with the values of $\lambda_{4}$ and $\lambda_{3}$ from Table I, indicate that indeed the error in euthyroid rats is insignificant, but in hypothyroid animals the area is $21 \%$ underestimated by applying $\lambda_{4}$ to the 24 -h serum $\left[{ }^{125} \mathrm{I}\right] \mathrm{T} 3(\mathrm{~T} 4)$ to integrate it to infinity. Therefore, the 24 to infinity integral calculated with $\lambda_{4}$ was multiplied by 1.26 in hypothyroid animals (Table VI).

\section{Acknowledgments}

The authors are grateful for the technical assistance of Maurice Castonguay, Sarah Mellen, and, particularly, Peggy Matthews.

This work was supported in part by National Institutes of Health grants AM-18616 and AM-07315.

\section{References}

1. Pittman, C. S., J. B. Chambers, Jr., and V. H. Read. 1971. The extrathyroidal conversion of thyroxine to triiodothyronine in normal man. J. Clin. Invest. 50:1187-1196.

2. Surks, M. I., A. R. Schadlow, J. M. Stock, and J. Oppenheimer. 1973. Determination of iodothyronine absorption and conversion of $L-$ thyroxine $\left(\mathrm{T}_{4}\right)$ to $\mathrm{L}$-triiodothyronine $\left(\mathrm{T}_{3}\right)$ using turnover rate techniques. J. Clin. Invest. 52:805-811.

3. Schwartz, H. L., M. I. Surks, and J. H. Oppenheimer. 1971. Quantitation of extrathyroidal conversion of L-thyroxine to 3,5,3'-triiodoL-thyronine in the rat. J. Clin. Invest. 50:1124-1130.

4. Chopra, I. J., D. H. Solomon, U. Chopra, S. Y. Wu, D. A. Fisher, and Y. Nakamira. 1978. Pathways of metabolism of thyroid hormones. Recent Prog. Horm. Res. 34:521-567. 
5. Visser, T. J., I. Van der Does-Tobe, R. Docter, and G. Hennemann. 1975. Conversion of thyroxine into triiodothyronine by rat liver homogenate. Biochem. J. 150:489-493.

6. Chiraseveenuprapund, P., U. Buergi, A. Goswami, and I. N. Rosenberg. 1978. Conversion of L-thyroxine to triiodothyronine in rat kidney homogenate. Endocrinology. 102:612-622.

7. Chopra, I. J. 1977. A study of extrathyroidal conversion of thyroxine $\left(\mathrm{T}_{4}\right)$ to $3,3^{\prime}, 5$-triiodothyronine $\left(\mathrm{T}_{3}\right)$ in vitro. Endocrinology. 101:453-463.

8. Oppenheimer, J. H., H. L. Schwartz, and M. I. Surks. 1972. Propylthiouracil inhibits the conversion of L-thyroxine to L-triiodothyronine. An explanation of the antithyroxine effect of propylthiouracil and evidence supporting the concept that triiodothyronine is the active thyroid hormone. J. Clin. Invest. 51:2493-2497.

9. Larsen, P. R., and R. D. Frumess. 1977. Comparison of the biological effects of thyroxine and triiodothyronine in the rat. Endocrinology. 100:980-988.

10. Leonard, J. L., and I. N. Rosenberg. 1978. Thyroxine 5'-deiodinase activity of rat kidney: observations on activation by thiols and inhibition by propylthiouracil. Endocrinology. 103:2137-2144.

11. Kaplan, M. M., J. B. Tatro, R. Breitbart, and P. R. Larsen. 1979. Comparison of thyroxine and 3,3',5'-triiodothyronine metabolism in rat kidney and liver homogenates. Metab. Clin. Exp. 28:1139-1146.

12. Silva, J. E., J. L. Leonard, F. R. Crantz, and P. R. Larsen. 1982. Evidence for two tissue specific pathways for in vivo thyroxine 5 '-deiodination in the rat. J. Clin. Invest. 69:1176-1184.

13. Visser, T. J., J. L. Leonard, M. M. Kaplan, and P. R. Larsen. 1982. Kinetic evidence suggesting two mechanisms by iodothyronine 5'-deiodination in rat cerebral cortex. Proc. Natl. Acad. Sci. USA. 79:5080-5084.

14. Visser, T. J., M. M. Kaplan, J. L. Leonard, and P. R. Larsen. 1983. Evidence for two pathways of iodothyronine $5^{\prime}$-deiodination in rat pituitary that differ in kinetics, propylthiouracil sensitivity, and response to hypothyroidism. J. Clin. Invest. 71:992-1002.

15. Leonard, J. L., S. A. Mellen, and P. R. Larsen. 1982. Thyroxine 5'-deiodinase activity in brown adipose tissue. Endocrinology. 112:11531155.

16. Silva, J. E., and P. R. Larsen. 1982. Comparison of iodothyronine 5 '-deiodinase and other thyroid-hormone-dependent enzyme activities in the cerebral cortex of hypothyroid neonatal rat. Evidence for adaptation to hypothyroidism. J. Clin. Invest. 70:1110-1123.

17. Weeke, J., and H. Orskov. 1973. Synthesis of $125 \mathrm{i}$ monolabelled $3,5,3^{\prime}$-triiodothyronine and thyroxine of maximum specific activity for radioimmunoassay. Scand. J. Clin. Lab. Invest. 32:357-360.

18. Kochupillai, N., and R. S. Yalow. 1978. Preparation, purification, and stability of high specific activity ${ }^{125}$ I-labelled thyronines. Endocrinology. 102:128-135.

19. Zimmerman, C. J., M. Izumi, and P. R. Larsen. 1978. Isolation of labeled triiodothyronine from serum using affinity chromatography: application to the estimation of the peripheral $T_{4}$ to $T_{3}$ conversion in rats. Metab. Clin. Exp. 27:303-313.

20. Oppenheimer, J. H., H. L. Schwartz, and M. I. Surks. 1975. Determination of common parameters of iodothyronine metabolism and distribution in man by noncompartmental analysis. J. Clin. Endocrinol. Metab. 41:319-324.

21. - 1975. Erratum: revised calculations of common parameters of iodothyronine metabolism and distribution by noncompartmental analysis. J. Clin. Endocrinol. Metab. 41:1172-1173.

22. Silva, J. E., J. L. Leonard, and P. R. Larsen. 1983. Relative in vivo potency of iodothyronines to inhibit cerebral cortex (cx) and pituitary (p) iodothyronine 5'deiodinase activity in hypothyroid rats. Prog. 65th Ann. Meet. Endocrine Soc., San Antonio. 202.

23. Larsen, P. R. 1976. Radioimmunoassay of thyroxine, triiodothyronine, and thyrotropin in human serum. In Manual of Clinical Immunology. N. R. Rose and H. Friedman, editors. American Society for Microbiology, Washington, DC. 222-230.

24. Kaplan, M. M., and R. D. Utiger. 1978. Iodothyronine metabolism in liver and kidney homogenates from hyperthyroid and hypothyroid rats. Endocrinology. 103:156-161.

25. Balsam, A., F. Sexton, and S. H. Ingbar. 1978. The effect of thyroidectomy, hypophysectomy, and hormone replacement on the formation of triiodothyronine from thyroxine in rat liver and kidney. Endocrinology. 103:1759-1767.

26. Harris, A. R. C., S. L. Fang, A. G. Vagenakis, and L. E. Braverman 1978. Effect of starvation, nutriment replacement and hypothyroidism on in vitro hepatic $\mathrm{T}_{4}$ to $\mathrm{T}_{3}$ conversion in the rat. Metab. Clin. Exp. 27:1680.

27. Oppenheimer, J. H., H. L. Schwartz, H. C. Shapiro, G. Bernstein, and M. I. Surks. 1970. Differences in primary cellular factors influencing the metabolism and distribution of 3,5,3'-L-triiodothyronine and L-thyroxine. J. Clin. Invest. 49:1016-1024.

28. DiStefano, J. J. III, M. Jang, T. K. Malone, and M. Broutman. 1982. Comprehensive kinetics of triiodothyronine production, distribution and metabolism in blood and tissue pools of the rat using optimized blood-sampling protocols. Endocrinology. 110:198-213.

29. DiStefano, J. J. III, T. K. Malone, and M. Jang. 1982. Comprehensive kinetics of thyroxine distribution and metabolism in blood and tissue pools of the rat from only six blood samples: dominance of large, slowly exchanging tissue pools. Endocrinology. 111:108-117.

30. Cullen, M. J., G. F. Doherty, and S. H. Ingbar. 1973. The effect of hypothyroidism and thyrotoxicosis on thyroxine metabolism in the rat. Endocrinology. 92:1028-1033.

31. Leonard, J. L., I. N. Rosenberg. 1980. Thyroxine 5'-deiodinase from rat kidney: substrate specificity and the 5'-deiodination of reverse triiodothyronine. Endocrinology. 107:1376-1383.

32. Foster, D. O., and M. L. Frydman. 1977. Nonshivering thermogenesis in the rat. II. Measurement of blood flow with microspheres point to brown adipose tissue as the dominant site of the calorigenesis induced by noradrenaline. Can. J. Physiol. Pharmacol. 56:110-122.

33. Joel, C. D. 1965. The physiological role of brown adipose tissue. In Handbook of Physiology. Adipose Tissue. A. E. Renold and G. F. Cahill, editors. American Physiological Society, Washington, DC. 5985.

34. Morris, R., S. M. Lum, E. M. Kaptein, C. A. Spencer, and T. J. Nicolof. Autoregulation of peripheral thyroxine $\left(T_{4}\right)$ to triiodothyronine $\left(\mathrm{T}_{3}\right)$ conversion in man. Clin. Res. 31:85a. (Abstr.)

35. Inada, M., K. Kasagi, S. Kurata, Y. Kazama, H. Takayama, K. Torizuka, M. Fucase, and T. Soma. Estimation of thyroxine and of triiodothyronine distribution and the conversion rate of thyroxine to triiodothyronine in man. J. Clin. Invest. 55:1337-1348.

36. Ladenson, P. W., P. D. Goldenheim, D. S. Cooper, M. A. Miller, and E. C. Ridgway. Early peripheral responses to intravenous L-thyroxine in primary hypothyroidism. Am. J. Med. 73:467-474.

37. Ladenson, P. W., P. D. Goldenheim, and E. C. Ridgway. Rapid pituitary and peripheral tissue responses to intravenous L-triiodothyronine in hypothyroidism. J. Clin. Endocrinol. Metab. 56:1252-1259.

38. Ridgway, E. C., J. A. McCammon, J. Benotti, and F. Maloof. Acute metabolic responses in myxedema to large doses of intravenous 1-thyroxine. Ann. Intern. Med. 77:549-55.

39. Crantz, F. R., J. E. Silva, and P. R. Larsen. 1982. An analysis of the sources and quantity of 3,5,3'-triiodothyronine and cerebellum. Endocrinology. 110:367-375. 